\title{
Relative importance of risk factors concerning the introduction and spread of classical swine fever and foot-and-mouth disease in Germany
}

\begin{abstract}
This paper describes the results of an expert survey in Germany to obtain the relative importance of risk factors for the introduction and spread of classical swine fever (CSF) and foot-and-mouth disease (FMD). 41 experts from five different fields were interviewed face-to-face, and 151 questionnaires were sent to experts working in the veterinary departments of five selected German federal states. In the questionnaire, experts were asked to estimate and rank situations presenting various degrees of danger. These situations were created by the respective risk factors being either "present" or "not present". The relative importance of each single risk factor was evaluated on the basis of Conjoint Analysis. The results of Conjoint Analysis were subjected to Cluster Analysis to determine whether the similarities in the experts' evaluation of risk situations might have been influenced by their working in the same field or in the same region. The evaluation of the risk factors indicates that for the introduction of CSF and FMD the import of livestock was seen as a great risk with relative importance at $26.1 \%$ / $27.0 \%$ (interview / questionnaire) for CSF and $25.3 \%$ / $27.7 \%$ for FMD, respectively. For CSF, wild boars present an additional risk at $26.8 \%$ / $20.8 \%$. The danger of spreading both animal diseases rests in indirect contacts in connection with high animal density (32.8 \% / $26.9 \%$ for CSF and $39.5 \%$ / $40.9 \%$ for FMD). Animal trade at $27.2 \%$ / $29.3 \%$ was also seen as a danger for the spread of FMD. Cluster Analysis did not show any influence by mutual external conditions. Results were validated by comparing to findings in the literature.
\end{abstract}

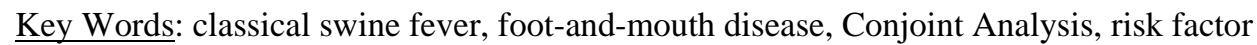

\section{Zusammenfassung}

Titel der Arbeit: Relative Bedeutung von Risikofaktoren für die Einschleppung und Verbreitung der Klassischen Schweinepest und der Maul- und Klauenseuche in Deutschland

Auf Basis einer Expertenbefragung wurde die relative Bedeutung von Risikofaktoren geschätzt, die für die Einschleppung der Klassischen Schweinepest (KSP) sowie der Maul- und Klauenseuche (MKS) nach Deutschland und deren Verbreitung innerhalb Deutschlands eine Rolle spielen. 41 Experten aus fünf verschiedenen Arbeitsbereichen wurden persönlich befragt. Zusätzlich wurden 151 Fragebögen an Experten aus Veterinärämtern fünf ausgewählter Bundesländer verschickt. Die Einschätzungen der Experten wurden einer Conjoint Analyse unterzogen. Mit den Ergebnissen aus der Conjoint Analyse wurde eine Clusteranalyse durchgeführt, die die Übereinstimmung in den Beurteilungen der Risikosituationen aufgrund desselben Arbeitsfeldes bzw. der Tätigkeit in derselben Region prüft. Für die Einschleppung der KSP und MKS wird das größte Risiko in dem Import von Lebendvieh gesehen (KSP: 26.1 / 27.0 \%; MKS: 25.3 / 27.7\%). Die Bedeutung der Wildschweine für die Einschleppung der KSP beträgt 26.8 / 20.8\%. Die größte Gefahr für die Verbreitung der KSP und MKS stellen die Risikofaktoren indirekte Kontakte und Viehdichte dar (KSP: 32.8 / 26.9\%; MKS: 39.5 / 40.9\%). Die Ergebnisse der Clusteranalyse zeigen keinen Einfluss der Tätigkeitsfelder und der Region auf die Einschätzung der Risikofaktoren.

Schlüsselwörter: Klassische Schweinepest, Maul- und Klauenseuche, Coinjoint Analyse, Risikofaktoren

\section{Introduction}

The outbreak of a reportable animal disease nearly always incurs high economic costs. Classical swine fever (CSF) is one of the most economically important infections in 
domestic swine (MOENNIG, 2000). PITTLER et al. (1995) estimated the total cost of the 1993-94 outbreak of CSF in Germany to be between 1.3 and 1.5 billion marks. Between 1993 and 1997, more than 2.1 million pigs were destroyed in Germany because of CSF (TEUFFERT et al., 1998). Domestic swine in the member states of the European Union are currently nearly free of CSF. Wild boars, on the other hand, are a problem because it is believed that the wild populations in Italy, France and Germany are infected (KADEN, 1998). A transfer of CSF from wild boar to domestic swine is possible at any time.

Foot-and-mouth disease (FMD) also is a costly disease (KRAMER et al., 1997). The major costs of an outbreak of FMD are from market closures and export stoppages, not the direct costs of slaughtering, compensation, etc.

To limit the losses an efficient method of control of the disease in case of an outbreak is of the greatest important. To support the control of infectious animal diseases, computer simulation models can be used. These models need specific input for individual infectious diseases. Some information is available from historical and experimental data. But it is difficult to derive general assumptions and properties. One way of determining estimates and properties is to consult experts on the subject. Conjoint Analysis (CA, a statistical method for deriving quantification of the relative importance of attributes of a product) can be helpful. HORST et al. (1996a) introduced this method for estimating the relative importance of risk factors concerning contagious animal diseases. We used CA in a survey of experts in Germany to establish the relative importances of risk factors for the introduction and spread of CSF and FMD in Germany.

\section{Materials and Methods}

\section{Interviews and questionnaires}

41 German experts from five different professional areas were personally interviewed regarding CSF and FMD by one person. Nine participants worked as swine practitioners. Six experts were responsible for establishing animal infectious disease policy and six experts were responsible for animal insurance. Three experts worked in animal disease funding, and 17 carried out research on infectious animal diseases. In order to participate in the personal interview experts, had to be involved in the outbreaks of CSF in Germany. The knowledge of experts about FMD was unknown, but this knowledge is also used to make decisions in real scenarios. Additionally, 151 questionnaires were sent to all officially licensed veterinarians in the states of Schleswig-Holstein (15), Mecklenburg-Vorpommern (18), Niedersachsen (45), Nordrhein-Westfalen (52) and Baden-Württemberg (21). These veterinarians are responsible for disease prevention, controlling and eradication in a defined district if an outbreak occurs. The states were selected in order to get estimates about the risk factors depending on the different structure (e.g. livestock density, farm size). This survey was carried out by mail because so many interviews were impractical.

\section{Conjoint Analysis}

Conjoint Analysis (CA) is a decompositional statistical method that allows a quantification of the relative importance of the attributes of a product or event in relation to the overall estimation of an individual with respect to this particular product 
or event (HORST et al., 1998). Respondents are requested to rank combinations of attributes which are designed scenarios or profiles. The ranks given by the respondents to the profiles are decomposed using regression analysis. The importance of each attribute results from its part-worth score. We used CA to determine the relative importance of selected risk factors (attributes) for the specific events of "introduction" and "spread" of CSF and FMD.

For CA, relevant risk factors and their distinctive features must be pre-selected. The selection was made based on the epidemiological characteristics of the CSF virus and the FMD virus, with reference to present studies in the scientific literature (HORST et al., 1996a; KAADEN, 1985; LIEBERMANN, 1992; MOENNIG, 1993; PITTLER et al., 1995; TEUFFERT et al., 1997; FRITZEMEIER et al., 1998).We used the risk factors listed in Tables 1 and 2. Each of these risk factors had two categories: "present" and "not present." The design of the survey was made with the help of the profiling method, according to which scenarios were created from each possible combination of risk factors being present. According to GREEN and SRINIVASAN (1990), this method functions reliably if only a limited number of factors are considered. A total number of five, six, or seven dichotomous risk factors results in 32, 64, or 128 possible scenarios (complete factorial design). However, the individuals being surveyed cannot deal with such large numbers of scenarios. Therefore, it is necessary to formulate a reduced design. The number of profiles can be reduced by using a fractional factorial design with only a small loss of accuracy. ADELMAN (1962) developed a number of 'basic plans' which can be used for the construction of profiles (scenarios). Using this design, eight scenarios for each of the four events were selected. In addition, three test profiles (see below) were included as holdouts so that altogether eleven scenarios were evaluated.

For CA, it is necessary to rank scenarios. The experts were asked to rank scenarios according to their importance. The most critical scenario was ranked first, the next most critical profile ranked second, and so on, until the least important situation was ranked at 11 . On the basis of the data on ranking obtained for the eight scenarios, a part-worth score for each risk factor was estimated by using a simple additive regression model as described by BACKHAUS et al. (1996). A common CA of the individual analyses was used in which the individuals were perceived as repetitions of the design of the study so that all question values were used for estimating the partworth scores. The relative importance of each risk factor was determined from the part-worth scores ascertained by taking the part-worth score of each factor and dividing it by the sum of all of the part-worth scores (total-worth score) multiplied by 100.

Three randomly chosen scenarios were added as holdouts in order to analyse the fit of the CA model (based on eight scenarios only). Pearson's R (correlation between the metrical total-worthscore and true rank) and Kendall's tau (correlation between true and estimated rank) were used to check the validity of all models.

\section{Cluster Analysis}

Cluster Analysis (CL) was used to investigate the results of CA. The individual analyses, grouped according to whether they were personal interviews or questionnaires, were subjected to CL to discover any similarities present in the evaluations based on similar work environments or regional influences. 
Homogeneous clusters were created with the Ward Method combining those individuals to groups with the lowest increase of a the predetermined measure of heterogeneity. The squared sum error was used as the measure of heterogeneity.

For the personal interviews five clusters were assumed according to the number of working areas. Members of the working areas were assigned to special clusters if any differences in the risk evaluation between working areas existed. The same method was applied to the federal states.

CA and CL were performed with the statistical package SAS (1998).

\section{Results}

\section{Response rate}

The ranking of the scenarios occurred in the personal interview with 41 experts with regard to CSF, and with 38 of the 41 experts for FMD. The absence of an answer from some participants was explained by an insufficient knowledge FMD. 78 questionnaires were returned, of which 66 were evaluable. With respect to the written questionnaire, 66 respondents evaluated the introduction of CSF, 65 the spread of CSF, 65 the introduction of FMD, and likewise 65 the spread of FMD. The positive response rate was $43 \%$.

\section{Fit of the model}

For the personal interview, Pearson's R and Kendall's tau ranged from 0.70 to 0.93 with a significant level always less then $\mathrm{p}<0.04$ indicating a good fit (eight profiles). The questionnaire showed slightly lower relationships. Kendall's tau for the three 'holdouts' profiles were lower (0.58-0.82) and the significance values increased to $\mathrm{p}>0.08$ indicating a sub-optimal fit.

\section{Conjoint Analysis}

The results of CA of the interviews and questionnaires concerning CSF are presented in Table 1 summarizing the part-worth score for each risk factor with its standard error (S.E.), as well as the relative importance in percentages obtained from the part-worth score per risk factor. In the interviews, the estimation at $26.8 \%$ for wild boar was similar to that for the import of livestock, $26.1 \%$. In the questionnaire, the evaluation for the import of livestock at $27.0 \%$ was similar to the evaluations of the interviews (26.1\%). Wild boar are regarded slightly less hazardous (20.8\%). The third most serious factor, the feeding of imported swill, was comparable at $18.3 \%$ in the interviews with $19.0 \%$ in the questionnaires. A discrepancy of $3.2 \%$ was evident with the risk factor import of animal products; all other factors lay close to each other in their relative importance. The part-worth scores of the survey varied between 0.18 and 1.48 (S.E. 0.109-0.113), while the questionnaire varied between 0.25 and 1.71 (S.E. $0.077-0.080)$.

The estimation of risk factors for the spread of CSF (Table 1) resulted in a relative importance for all factors between $19.9 \%$ (animal trade) and $13.2 \%$ (indirect contact). The questionnaire, on the other hand, identified a non-apparent infection as the greatest risk factor (23.4\%). It was followed by swill feeding (18.9 \%), livestock density and wild boar with approximately $16.5 \%$. There was a difference of up to 7.2 
$\%$ between the relative importance of non-apparent infections from the interviews and the questionnaires. The part-worth scores of the survey had values between 0.80 and 1.20 (S.E. 0.105-0.109), and the value of the questionnaire varied between 0.66 and 1.50 (S.E. 0.076-0.079).

Table 1

Risk factors for the introduction and spread of CSF (Risikofaktoren für die Einschleppung und Verbreitung der Schweinepest)

\begin{tabular}{|c|c|c|c|c|c|c|}
\hline \multirow[b]{2}{*}{ Risk factor } & \multicolumn{3}{|c|}{ Personal interview $(n=41)$} & \multicolumn{3}{|c|}{ Questionnaire $(\mathrm{n}=66)$} \\
\hline & $\begin{array}{l}\text { Part- } \\
\text { worth } \\
\text { score }\end{array}$ & S.E. & $\begin{array}{l}\text { Relative } \\
\text { Importance } \\
\%\end{array}$ & $\begin{array}{l}\text { Part- } \\
\text { worth } \\
\text { score }\end{array}$ & S.E. & $\begin{array}{l}\text { Relative } \\
\text { Importance } \\
\%\end{array}$ \\
\hline \multicolumn{7}{|l|}{ Introduction } \\
\hline Import of livestock & 1.44 & 0.11 & 26.1 & 1.71 & 0.08 & 27.0 \\
\hline Returning livestock trucks & 0.50 & 0.11 & 9.1 & 0.52 & 0.08 & 8.1 \\
\hline Airborne transmission & 0.18 & 0.11 & 3.2 & 0.25 & 0.08 & 4.0 \\
\hline Feeding of imported swill & 1.01 & 0.11 & 18.3 & 1.21 & 0.08 & 19.0 \\
\hline Wild boar & 1.48 & 0.11 & 26.8 & 1.32 & 0.08 & 20.8 \\
\hline Tourism & 0.43 & 0.11 & 7.7 & 0.56 & 0.08 & 8.9 \\
\hline Import of animal products & 0.49 & 0.11 & 8.8 & 0.78 & 0.08 & 12.2 \\
\hline \multicolumn{7}{|l|}{ Spread } \\
\hline Swill feeding & 0.84 & 0.11 & 13.8 & 1.22 & 0.08 & 18.9 \\
\hline Indirect contact & 0.80 & 0.11 & 13.2 & 0.66 & 0.08 & 10.2 \\
\hline Livestock density & 1.19 & 0.11 & 19.6 & 1.08 & 0.08 & 16.7 \\
\hline Animal trade & 1.20 & 0.11 & 19.9 & 0.93 & 0.08 & 14.5 \\
\hline Wild boar & 1.05 & 0.11 & 17.3 & 1.05 & 0.08 & 16.3 \\
\hline Non-apparent infections & 0.98 & 0.11 & 16.2 & 1.50 & 0.08 & 23.4 \\
\hline
\end{tabular}

For the introduction of FMD there was good agreement between the survey and the questionnaire (2). The greatest risk with $25.3 \%$ and $27.7 \%$ - likewise for the introduction of CSF - was assigned to the import of livestock. Feeding imported swill was in second place, at $18.4 \%$ in the survey and $17.4 \%$ on the questionnaire. The part-worth scores of the interviews ranged between 0.38 and 1.50 (S.E. 0.1130.120 ), and for the questionnaires between 0.53 and 1.80 (S.E. 0.076-0.080).

Table 2 shows the comparison for the spread of FMD. Animal trade was seen as the most dangerous risk factor in both the survey and the questionnaire with relative importance at $27.2 \%$ and $29.3 \%$. The further order of the risk factors differed. There are varieties of $2.0 \%$ to $5.8 \%$ between the relative importance. The part-worth scores of the survey had values between 0.73 and 1.41 (S.E. 0.100-0.105) and the value of the questionnaire ranged between 0.71 and 1.53 (S.E. 0.072-0.076).

\section{Cluster Analysis}

Table 3 gives an example of the CL using the results of the CA for the spread of CSF based on the questionnaire and the five federal states. Five clusters were assumed so that five clusters would result in which the individuals from the same states are 
classified together if the results had been influenced by the states. The results demonstrated that individuals were distributed randomly over the five clusters independent of the work area or region. The same findings were obtained for the other scenarios so that the risk evaluation of the introduction and spread of CSF and FMD remained unaffected by the work area or federal states.

Table 2

Risk factors for the introduction and spread of FMD (Risikofaktoren für die Einschleppung und Verbreitung der Maul- und Klauenseuche)

\begin{tabular}{|c|c|c|c|c|c|c|}
\hline \multirow{4}{*}{ Risk factor } & \multicolumn{3}{|c|}{ Personal interview $(n=38)$} & \multicolumn{3}{|c|}{ Questionnaire $(n=66)$} \\
\hline & & S.E. & Relative & Part- & S.E. & Relative \\
\hline & worth & & Importance & worth & & Importance \\
\hline & & & & & & \\
\hline \multicolumn{7}{|l|}{ Introduction } \\
\hline Import of livestock & 1.50 & 0.12 & 25.3 & 1.80 & 0.08 & 27.7 \\
\hline Returning livestock trucks & 0.75 & 0.12 & 12.6 & 0.79 & 0.08 & 12.1 \\
\hline Airborne transmission & 0.38 & 0.11 & 6.3 & 0.53 & 0.08 & 8.2 \\
\hline Feeding of imported swill & 1.09 & 0.12 & 18.4 & 1.13 & 0.08 & 17.4 \\
\hline Wildlife & 0.58 & 0.12 & 9.8 & 0.61 & 0.08 & 9.5 \\
\hline Tourism & 0.97 & 0.12 & 16.4 & 0.89 & 0.08 & 13.7 \\
\hline Import of animal products & 0.67 & 0.12 & 11.2 & 0.74 & 0.08 & 11.4 \\
\hline \multicolumn{7}{|l|}{ Spread } \\
\hline Swill feeding & 0.73 & 0.11 & 14.1 & 0.85 & 0.08 & 16.2 \\
\hline Indirect contact & 1.03 & 0.11 & 19.8 & 0.93 & 0.08 & 17.8 \\
\hline Livestock density & 1.02 & 0.10 & 19.6 & 1.21 & 0.07 & 23.1 \\
\hline Animal trade & 1.41 & 0.11 & 27.2 & 1.53 & 0.08 & 29.3 \\
\hline Airborne transmission & 1.00 & 0.10 & 19.3 & 0.71 & 0.07 & 13.6 \\
\hline
\end{tabular}

S.E. Standarderror

Table 3

Distribution of the respondents $(n=65)$ from the federal states to the clusters considering the spread of CSF as an example (Verteilung der Teilnehmer aus den Bundesländern auf fünf Cluster am Beispiel der Verbreitung der Schweinepest)

\begin{tabular}{llllll}
\hline Cluster & & \multicolumn{2}{c}{ Federal States } \\
& $\begin{array}{l}\text { Schleswig- } \\
\text { Holstein }\end{array}$ & $\begin{array}{l}\text { Mecklenburg- } \\
\text { Vorpommern }\end{array}$ & $\begin{array}{l}\text { Baden- } \\
\text { Württemberg }\end{array}$ & $\begin{array}{l}\text { Nordrhein- } \\
\text { Westfalen }\end{array}$ & Niedersachsen \\
\hline 1 & 2 & 2 & 3 & 5 & 6 \\
2 & 1 & 7 & 2 & 11 & 5 \\
3 & 1 & 1 & 0 & 3 & 6 \\
4 & 0 & 0 & 0 & 1 & 2 \\
5 & 1 & 1 & 0 & 3 & 2 \\
\hline $\begin{array}{l}\text { Respondents } \\
\text { per state }\end{array}$ & 5 & 11 & 5 & 23 & 21 \\
\hline
\end{tabular}




\section{Discussion}

\section{Method of Questioning}

CA is a relatively new method in the area of veterinary epidemiology. The great advantage of CA compared to direct interviews is the possibility of a representation of risk scenarios providing realistic scenarios to the respondent (HORST, 1998). A further positive aspect is the low sensitivity as opposed to the number of participants. HORST et al. (1996b) tested the influence of the quota of answers on the results with the help of a selection of random sample answers and concluded that the results were influenced only to a minor degree. Therefore, CA can also be used, even if only a small group of experts are assembled.

The survey was performed as a personal interview or a mailed questionnaire. Personal interviews were carried out with 41 experts from five different work areas. One advantage of the interviews as opposed to the questionnaires was in the high rate of participation. Another positive aspect of the personal interview was the possibility of immediate intervention if confusion arised concerning the questions. However, the possibility that the presence of an interviewer might influence the interview is often seen as a disadvantage (HOLM, 1986). Interviewer variation was avoided since a single person carried out the interviews. Personal interviews are more costly and time demanding than mailed surveys.

The main advantages of postal questionnaires were the lower costs and the higher number of participants that could be included. Influence by the interviewer was also avoided. A disadvantage was the lack of interest (shown by some contacted people), because only $52 \%$ of the mailed questionnaires were returned.

\section{Fit of the model}

The fit of the simple additive model (eight scenarios) was adequately indicated by the high correlations and the significance level $p<0,04$. This is confirmed by the low S.E. of the path-worth score, which also emphasized the strong relationships between the empirical and estimated ranks (BACKHAUS et al., 1996). Questioning technique and diseases affected the fit to a minor degree. Using the three 'holdouts', Kendall's tau was lower with an increased significance level $(p>0,08)$ showing an unsatisfactory fit of the model. The lack of fit for the 'holdout' scenarios could be caused by the small number of profiles since small changes in values can affect the ranking significantly. Another reason could be an inadequate knowledge of the participants resulting in conflicting responses. Due to the limited number of 'holdouts', it is difficult to arrive at a definite conclusion.

\section{Risk Factors}

\section{Risk factors for the introduction of CSF into Germany}

Wild boar as well as the import of livestock were regarded as the most critical risk factors for the introduction of CSF into Germany. With regard to imports, this is in accordance with the results of a survey of experts carried out by HORST et al. (1996b), which determined that the import of livestock was the most serious factor for the introduction of CSF into the Netherlands. In the same study, the feeding of imported swill was regarded as the second most hazardous factor. This risk factor was 
ranked number three for the introduction of CSF into Germany, although the relative importance ranked the same in quantity as in the Dutch study.

German experts regarded wild boar as a great danger for the introduction of CSF. At present, Germany is the country most highly affected by CSF in the wild boar population within the EU (OLLENSCHLÄGER, 1999). FRITZEMEIER et al. (1998) discovered that in the years 1993 to 1997 primary outbreaks in Germany were caused directly by the feeding of infected, imported meat, or indirectly by the introduction of the CSF virus in the wild boar population and subsequent contact with domestic swine. TEUFFERT et al. (1997) saw direct and indirect contact with wild boar and feeding of swill as the the main causes of the first outbreaks in Germany between the years 1993 to 1997.

According to the opinion of WALDMANN et al. (1995) the Federal Republic of Germany is especially frequently hit by outbreaks of CSF since it is a transit-country with open borders to the east. Wild boar meat was documented as partially responsible for the first introduction of CSF into Germany. Live wild boar as well as other meat and sausage products likewise came into consideration. WALDMANN et al. (1995) placed no importance on the introduction of the virus by persons, vehicles, or live swine, which is in opposition to the results of the present survey of experts. In the survey, the risk posed by the import of livestock was seen as particularly great. The risk factor included the import of legal as well as illegal live swine, which explained the high estimation of this risk.

\section{Risk factors for the spread of CSF within Germany}

According to PITTLER et al. (1995), reasons for the spread of CSF in Germany in 1994 were not identified in $43 \%$ of all cases. Reasons given for the dissemination were swill feeding (2\%), wild boar (7\%), and purchase $(17 \%) .31 \%$ of the cases fell within the category of risk from indirect contact (proximity, vehicles, persons). From this, it can be deduced that part of the relative importance presented in this study are in each case found among the portion of unknown cases. Accordingly, the risk of swill feeding $(13.8 \%$ or $18.9 \%)$ is significantly higher than the $2 \%$ given. Likewise, the estimated risk of $16.3 \%$ or $17.3 \%$ attributed to wild boar was substantially higher than the $7 \%$ identified by PITTLER et al. (1995). If livestock density and proximity were combined, factors of animal density and indirect contact together received an importance of $26.9 \%$ or $32.9 \%$. These values reflected more or less the same $31 \%$ from the results of PITTLER et al. (1995). The estimated effect of purchase (17\%) was more less the same as our estimate of the importance of animal trade and animal marketing (14.5\% and $19.9 \%$, respectively).

FRITZEMEIER et al. (1998) investigated the outbreaks of CSF in the years 1993 to 1997. The number of unclear cases was $22 \%$. Swill feeding at $6 \%$ was given a somewhat higher value than in PITTLER et al. (1995) but did not reach the values determined by this study of $13.8 \%$ or $18.9 \%$. Wild boar at $14 \%$, on the other hand, came close to the values gained from the survey of $16.3 \%$ or $17.3 \%$. , indirect contacts (proximity, persons, and vehicles) with 38 \% were given a greater importance than in our interviews with experts.

The factor appearing in the questionnaire of non-apparent infection was chosen because of the ability of the CSF virus to pass through the placenta. If the passage occurs at a certain time during the pregnancy, the piglets born are not recognizably 
sick but carry the virus. If these animals then come onto the market, the virus can spread without being noticed initially. Here, a special risk of animal marketing and animal trade is found. In comparison with current data, the factor of animal trade was grouped together with non-apparent infection. They then had an importance of $36.1 \%$ or $37.9 \%$, which was higher than the $20 \%$ given for animal traffic. In conclusion, the unclear cases can probably be attributed to this risk.

Risk factors for the introduction of FMD into Germany

The newest data from current outbreaks of FMD have not yet been fully evaluated. THALMANN and NÖCKLER (2001) assumed that the introduction of FMD in Great Britain, the Netherlands and France was caused by the illegal import of meat and swill feeding. Comparison with cases from other parts of the world in which FMD is still endemic are hardly helpful since veterinary measures taken to control the disease occur on different levels. Often the introduction of FMD into other countries is connected with the uncontrolled importation of small ruminants, since these animals are usually only sub-clinically sick and therefore not subject to regulations (KITCHING, 1998).

The study by HORST et al. (1996b) on the introduction of FMD in the Netherlands showed little agreement with our results. Indeed, although the import of livestock into the Netherlands is likewise seen as the most critical factor, it is given much greater importance than German experts ascribed to it. All further calculations diverged. One possible reason for different results is the growing expectation in recent years of the introduction of FMD. Therefore, the interest of experts in this phenomenon has been augmented, leading to new explanations of the possible reasons for introduction.

KITCHING (1998 and 1999), in his overview of the FMD situation around the world in recent years, suggested possible reasons for the introduction of FMD. He found that frequently the virus is brought into a country by the import of live animals. Often criminal behavior, such as the falsification of transport papers, is a significant factor. Furthermore, infection of a herd and the use of infected transport vehicles are probably connected. A third way is the import of infected animal products. In any case, the risk of introducing FMD has increased, if only from the recent expansion of international trade of live animals as well as of animal products.

Risk factors for the spread of FMD within Germany

On account of cases of FMD in Southern Europe in 1996, the national crisis center for the control of infectious animal diseases (ANONYMOUS, 1997) calculated a risk evaluation for this disease. Marketing animals outside the region was regarded as the greatest danger for the spread of FMD. Regular and irregular contacts with and between individual operations represented additional risks.

KITCHING (1998) also listed trade as a risk for the spread of FMD. Furthermore, he listed the carrying of the virus by persons as a hazard.

\section{Conclusion}

In conclusion, a survey of experts seemed to be a legitimate method for gathering data in cases where field data are not available or are inadequate. Conjoint Analysis for determining relative importance was a helpful method in such a case. 
The results of the personal interviews and the mailed questionnaires showed no essential differences. Thus, it was shown that a survey of experts can be undertaken by mailing out questionnaires. Careful preparation and processing of the questionnaire assured that a sufficiently large number of answers were obtained.

The evaluation of the risk factors concurred that for the introduction of CSF and FMD the import of livestock as well as the feeding of imported swill were seen as great dangers. For CSF, wild boar present an additional risk. The danger of spreading both animal diseases rested mainly in indirect contacts in connection with high animal density. Especially, the characteristics of proximity, persons and vehicles as means of indirect contact were frequently mentioned. Animal trade was also seen as a risk. It was determined that the CA was a useful tool for survey of experts. The survey produced useful expert opinion as an alternative to limited available field data.

\section{References}

ADDELMAN, S.:

Orthogonal Main-Effect Plans for Asymmetrical Factorial Experiments. Technometrics 4, 21-46, 1962

ANONYMUS,

Risikoanalyse zur Maul- und Klauenseuche (MKS), Nationales Krisenzentrum Tierseuchenbekämpfung im BML, Amtstierärztlicher Dienst und Lebensmittelkontrolle 4, 54-55, 1997

BACKHAUS, K.; ERICHSON, B.; PLINKE, W.; WEIBER, R.:

Multivariate Analysemethoden, Eine anwendungsorientierte Einführung. 8. Auflage. Berlin, Heidelberg, New York: Springer, 661pp, 1996

FRITZEMEIER, J.; MOENNIG, V.; STAUBACH, C.; TEUFFERT, J.; THULKE, H.-H.; SCHLÜTER, H.:

Untersuchungen zu Vorkommen, Ausbreitung und Bekämpfung der klassischen Schweinepest (KSP) in Deutschland 1993-1995, Abschlußbericht zum Forschungsprojekt 96HS022, Institut für Virologie der Tierärztlichen Hochschule Hannover, Institut für Epidemiologie der BFAV Wusterhausen, 50pp, 1998

GREEN, P.E.; SRINIVASAN, V.:

Conjoint Analysis in Marketing: New Developments With Implications for Research and Practice. J. Mark. 54, 3-19, 1990

HOLM, K.:

Die Befragung 1, Der Fragebogen - Die Stichprobe. Dritte Auflage. UTB Francke (Francke Verlag Tübingen), 209pp, 1986

HORST, H.S.:

Risk and economic consequences of contagious animal disease introduction. Wageningen Agricultural University, Netherlands, Department of Economics and Management, Mansholt Institute, Studies 11, 144pp, 1998

HORST, H.S.; DIJKHUIZEN, A.A.; HUIRNE, R.B.M.; DE LEEUW, P.W.:

Introduction of contagious animal diseases into The Netherlands: elicitation of expert opinions. Livest. Prod. Sci. 53 (1998), 253-264

HORST, H.S.; DIJKHUIZEN, A.A.; HUIRNE, R.B.M.; STEENKAMP, J.-B.E.M.; THRUSFIELD, M.V. (ED.);

GOODALL, E.A. (ED.):

Eliciting expert opinions on risk factors concerning introduction of virus: application of conjoint analysis. Society for Veterinary Epidemiology and Preventive Medicine, University of Glasgow, March 1996, 8-17, 1996a

HORST, H.S.; HUIRNE, R.B.M.; DIJKHUIZEN, A.A.:

Eliciting the relative importance of risk factors concerning contagious animal diseases using conjoint analysis: a preliminary survey report. Prev. Vet. Med. 27 (1996b), 183-195

KAADEN, O.-R.:

Luft als Vektor viraler Krankheitserreger. Tierärztl. Umsch. 40 (1985), 4-8

KADEN, V.:

Zur Situation der Klassischen Schweinepest beim Schwarzwild in der Europäischen Gemeinschaft und zu einigen Aspekten der Seuchenverbreitung. Berl. Muench. Tierärztl. Wschr. 111 (1998), 201-207

KITCHING, R.P.:

A Recent History of Foot-and-Mouth Disease. J. Comp. Path. 118 (1998), 89-108

KITCHING, R.P.:

Foot-and-mouth disease: current world situation. Vaccine 17 (1999), 11772-1774 
KRAMER, M.; JENTSCH, D.; KADEN, V.; SCHLÜTER, H.; ZWINGMANN, W.: Die Maul- und Klauenseuche-Situation in Europa und der Welt im Jahr 1996. Amtstierärztlicher Dienst und Lebensmittelkontrolle 4, 196-202, 1997

LIEBERMANN, H.: Lehrbuch der veterinärmedizinischen Virologie. Stuttgart: Fischer, 1992

MOENNIG, V.: Schweinepest - Verlaufsformen und Diagnostik. Prakt. Tier., coll. vet. XXIV, 76-78, 1993

MOENNIG, V.: Introduction to classical swine fever: virus, disease and control policy. Vet. Microbiol. 73 (2000), 93102

OLLENSCHLÄGER, B.:

Änderung der Schweinepest-Verordnung. Deutsches Tierärzteblatt 47 (1999), 1024-1025

PITTLER, H.; FIELDER, J.; JENTSCH, D.; HASSELBACH, P.; KRAMER, M.:

Der Schweinepest-Seuchenzug 1993/94, Probleme und Konsequenzen. Tierärztl. Umsch. 50 (1995), 522-530

SAS:

SAS Users Guide (Release 6.03). SAS Institute, Cary, NC, USA, 1998

TEUFFERT, J.; KRAMER, M.; SCHLÜTER, H.:

Zur Epidemiologie der Schweinepest in Deutschland unter besonderer Berücksichtigung der Aufgaben des praktischen Tierarztes. Prakt. Tier. coll. vet. XXVIII, 45-49, 1998

TEUFFERT, J.; SCHLÜTER, H.; KRAMER, M.:

Europäische Schweinepest, Übersicht zur internationalen (Europa) Schweinepestsituation - ermittelte Einschleppungsursachen und Verschleppungsrisiken. Dtsch. Tierärzteblatt 45 (1997), 1078-1080

THALMANN, G.; NÖCKLER, A.:

Das Auftreten der Maul- und Klauenseuche - ein historischer Überblick. Dtsch. Tierärztl. Wschr. 108 (2001), 484-494

WALDMANN, K.H.; WENDT, M.; GEISER, K.; BOLLWAHN, W.:

Schweinepest in Niedersachsen - Ergebnisse einer Klausurtagung. Deutsches Tierärzteblatt 43 (1995), 9-10

Received: 2003-06-25

Accepted: 2003-10-14

Author`s address

Dr. vet. med. BETTINA NISSEN, Prof. Dr. habil. JOACHIM KRIETER

Institut für Tierzucht und Tierhaltung der Christian-Albrechts-Universität zu Kiel

Olshausenstraße 40

D-24098 Kiel

Germany 